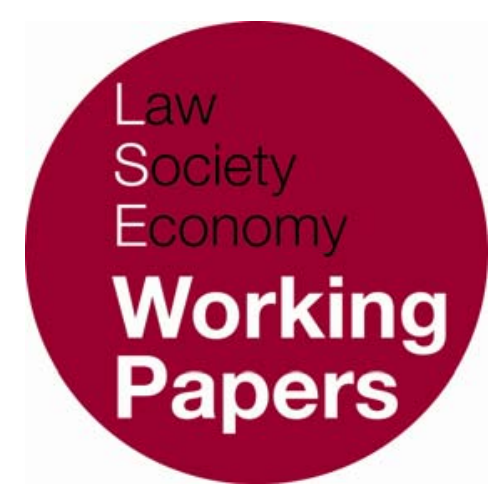

\title{
'One market, one law, one money?' Unintended consequences of EMU, enlargement, and eurocentricity
}

\author{
Giandomenico Majone
}

LSE Law, Society and Economy Working Papers 1/2007

London School of Economics and Political Science

Law Department

This paper can be downloaded without charge from LSE Law, Society and Economy

Working Papers at: www.lse.ac.uk/collections/law/wps/wps.htm and the Social Science Research Network electronic library at: http:/ / ssrn.comabstract=999652.

(C) Giandomenico Majone. Users may download and/or print one copy to facilitate their private study or for non-commercial research. Users may not engage in further distribution of this material or use it for any profit-making activities or any other form of commercial gain. 


\title{
'One market, one law, one money?' Unintended consequences of EMU, enlargement, and eurocentricity
}

\author{
Giandomenico Majone*
}

\begin{abstract}
A Union of twenty-seven, or more, members at vastly different levels of socioeconomic development must be considered a mutant of the old EU-15, not to mention the original EEC. The mutation pressures to which the EU is exposed today are to a large extent the unanticipated consequences of the application of the old integration methods under radically new conditions. Thus EMU, instead of making the integration process irreversible, has split the Union into two, possibly three, camps. On the other hand, the heterogeneity of EU-27 impedes the establishment of a Single Market for services. Many of the same people who opposed the original (Bolkestein) General Services Directive also maintain that the EU should be much more than a free-trade area. With the services sector - more than two-thirds of the economy - still largely regulated at the national level, however, it can no longer be excluded that the enlarged EU may regress, if not to the stage of a free-trade area, then to a customs union, with some elements of a common market for goods. It seems likely that the EU will no longer follow a straight-line evolution, rather a kind of evolution with many side branches. It is suggested that the economic theory of clubs provides a better theoretical framework for understanding such developments than the received conceptualizations.
\end{abstract}

\section{MUTATION PRESSURES}

Many, perhaps most, students of the EU seem to believe that the approaches to integration that have been followed for half a century are still basically valid, and capable of evolving in response to changing problems and new priorities. I do not share this optimistic view; on the contrary, in this presentation I shall try to show that methods that were reasonably successful in promoting integration under the economic, social, and geopolitical conditions prevailing during the trente glorieuses 1945-1975, are in need of radical reforms if they are to respond adequately to the mutation pressures of recent years. Please note that I am referring here to the traditional methods of European integration - both formal ones, like the

\footnotetext{
* Professor of Public Policy, Emeritus, European University Institute, Florence. Public Lecture given at the London School of Economics, Department of Law, 24 April 2007.
} 
Community Method, and informal ones, like the Monnet method of integration by stealth - rather than to the EU itself. I am not denying that the Union may be able to evolve in response to the new challenges; but my guess is that it will not be straight-line evolution (what biologists call orthogenesis), rather a kind of evolution with many side branches, like that of the modern Equus. The inadequacy of the traditional methods is most clearly revealed by their inability to deal with the unintended consequences of ambitious projects, such as monetary union and eastern enlargement. Also euro-centricity - the tendency to take the European dimension as the only relevant one in policy design - is the source of a number of undesirable consequences in an integrating world economy.

The world familiar to the founding fathers of communitarian Europe was vastly different from the one of today. The European economy during the period of reconstruction and recovery was built around the application of existing technologies, mass production, and an industrial structure dominated by large firms with stable markets and long-term employment. Not surprisingly, the institutions and policies of that period no longer seem to be effective in the world of today, characterized by globalization, flexibility, technological innovation, and an epochal shift from the production of goods to the provision of services. As a consequence, the EU is increasingly perceived as being unable to produce the public goods - especially a dynamic, competitive economy - which citizens expect as the pay-off of integration.

The geopolitical changes have been no less dramatic. Western Europe never seemed to be so close to being recast into a full-fledged supranational federation as in the 1950s. Among the factors which could have made possible such a farreaching transformation of the first European Communities were the Soviet threat - true or imagined - but, even more, the existence of the iron curtain, which for the first time since the collapse of the Roman limes, seemed to give a well-defined and stable boundary to the European heartland. Behind the iron curtain, communitarian Europe formed an island of democracy, with borders as precisely drawn as the Atlantic and the Pacific coasts of the United States. A shared history and a common territory are generally considered essential preconditions for the formation of a sense of nationality. The clearly defined territory of the EC could have favoured the development of a true European identity and, in time, even of something like a European nation. As Jean-Marie Guéhenno has pointed out, however, one of the unanticipated consequences of the collapse of the Soviet empire is the discovery that Europe can no longer become a nation, even a federal one. For this would require a definite boundary to the east, hence the permanent exclusion from the EU of the Russia of Tolstoi and Dostoievski. ${ }^{1}$ The current debate about the accession of Turkey only emphasizes the paradoxical character of the dilemma - widening or deepening? - facing the Union. When the Treaties of Paris and Rome were signed nobody could have foreseen that the Soviet system would collapse before the end of the century, making it possible for the countries

1 J.M. Guéhenno, La Fin De La Démocratie (Paris: Flammarion, 1993) 76-77. 
of Central and Eastern Europe to join the EU. However beneficial in so many respects, this particular mutation of the geopolitical environment has radically changed the nature of a fairly homogeneous association of mostly prosperous West European states. Today, socioeconomic conditions in the EU-27 are so heterogeneous that income inequality, as measured by the Gini coefficient, is greater in the Union than in the arch-capitalist USA. Average labour costs vary from $€ 27,60$ per hour in Germany to $€ 5$ in Eastern Europe. One obvious consequence is that the model of a 'social Europe' strongly committed to furthering socioeconomic equality, or at least greater inter-state cohesion, through income transfers is no longer credible. A second consequence is that the resulting heterogeneity of national policy preferences entails exponentially rising costs of uniform policies and, as we shall see, threatens the very notion of a Single European Market.

At the ideological level, heterogeneity challenges one of the basic tenets of the orthodox approach to European integration: the principle that integration should only be one way. This dogma of 'orthogenetic evolution' was enunciated with particular emphasis during the debate on the Maastricht Treaty. The perceived loss of unity of the Community legal order, allegedly caused by the restriction of the Community Method to the first pillar, and the likely effect on the acquis communautaire of the many opt-outs and derogations contained in the Treaty, attracted much critical comment. One of the severest criticisms was expressed by Deirdre Curtin in an article titled 'The Constitutional Structure of the Union: A Europe of Bits and Pieces'.2 Professor Curtin concluded her analysis with pretty strong words:

The result of the Maastricht summit is an umbrella Union threatening to lead to constitutional chaos... at the heart of all this chaos and fragmentation, the unique sui generis nature of the European Community, its true world-wide historical significance, is being destroyed. The whole future and credibility of the Communities as a cohesive legal unit which confers rights on individuals and which enters into their national legal systems as an integral part of those systems, is at stake. ${ }^{3}$

The loss of legal unity - a worrisome indication of which was what Curtin called the 'hijacking' by the drafters of the Treaty of the acquis binding all member states to the same body of legal rules and principles - was said to be fatal because 'built into the principle of an 'ever closer union among the peoples of Europe' is the notion that integration should only be one way'. ${ }^{4}$

Those who, like Professor Curtin, believe that European integration must move along a straight line, presumably in a federal direction, were naturally

2 D. Curtin, 'The Constitutional Structure of the Union: A Europe of Bits and Pieces' (1993) 30 Common Market Law Review 17.

3 ibid 67; emphasis in the original.

4 ibid; emphasis added. 
alarmed by the loss of unity symbolized by the pillar structure of the Maastricht Treaty. It is by now clear, however, that the differentiation or flexibility which appeared in several forms in the Treaty was no momentary aberration, but the clear indication of an emergent strategy for achieving progress in politically sensitive areas, even at the price of a loss of overall coherence of the system. ${ }^{5}$ Taken individually, the instances of flexibility - such as the opt-outs from monetary union, or the exemption from defence policy provisions of member states that are neutral - seemed not to be quite new. Flexibility had appeared in various forms in earlier Community history, including in the 1987 Single European Act, which with Article 100a(4) (now Article 95(4) EC) had made possible for the first time opting out of Community harmonization measures. Already then this possibility of unilateral derogation of harmonizing measures had alarmed influential commentators such as Pierre Pescatore, a former judge at the European Court, who feared that Article 100a(4) represented a serious backward step in the pattern of a uniform Community legal order. Actually, the idea of a common market structured by uniform European rules had already been given up by the early 1970s, when it became clear that total harmonization confers on the Community an exclusive competence which it is ill-equipped to discharge. ${ }^{6}$ The heterogeneity that the EU-27 is facing today, however, is orders of magnitude greater than anything that confronted the old Community. Derogations, opt-outs, options in directives may have been sufficient forms of flexibility in the past; what is needed today is nothing short of a radical recasting of existing institutional arrangements and traditional integration methods. For example, there are good reasons to question whether key elements of the Community Method like the Commission's monopoly of legislative and policy initiative, are still justified today. ${ }^{7}$ Paradoxically, many of today's problems are the unintended consequences of what have officially been celebrated as the two major achievements of recent years: Economic and Monetary Union (EMU), and the mutation of EU-15 into EU-27.

\section{A SINGLE CURRENCY IN SEARCH OF A SINGLE MARKET}

From the founding treaties to the ill-fated draft Constitutional Treaty, the finality of the process of European integration has been defined in terms of an openended commitment to 'ever closer union among the peoples of Europe' - or equivalent language. Operationally, this was always interpreted as implying, at a minimum, ever closer economic integration. Thus EMU was presented as the natural completion of the Single European Market. In 1990 the European

5 P. Craig and G. de Búrca, EU Law: Text, Cases, and Materials (Oxford: Oxford University Press, 3rd ed, 2003).

${ }^{6}$ S. Weatherill, Law and Integration in the European Union (Oxford: Clarendon Press, 1995).

${ }^{7}$ See section 5 below and G. Majone, The Would-Be World Power: the European Union at Fifty (2007, mimeo) ch.4. 
Commission published a study titled One Market, One Money: An Evaluation of the Potential Benefits and Costs of Forming an Economic and Monetary Union. ${ }^{8}$ According to this study the direct benefits - linked to the elimination of the costs of foreign exchange transactions and of the uncertainty associated with exchange fluctuations - would be relatively small, while the dynamic gains were expected to be much larger. The creation of a single currency, the Commission argued, would enhance the credibility of the internal market and the gains associated with its completion: 'one market', 'one legal system', and now 'one money'. The adoption of the euro (at that time still called ECU) as an international currency, was supposed to bring also seigniorage gains resulting from the readiness of foreigners to hold the new currency. Finally, a common monetary policy vis-à-vis the rest of the world would produce gains in prestige and political power. Many proponents of monetary union saw the single currency as a political project to liberate Europe from its dependence on the dollar. This was the idea of creating a 'European monetary personality', as it was called, and a currency able to rival the dollar on world monetary markets. In this sense Dutch Prime Minister Wim Kok spoke of EMU as 'the foundation for Europe's increased power in the world'.?

Today we know that the expectations about the benefits of monetary union were vastly exaggerated, and that the costs of one-size-fits-all policy were underestimated. Thus, while the single currency was supposed to facilitate intraEU trade, the volume of such trade has been decreasing for the last ten years: the introduction of the euro has not inverted but actually accelerated (because of the overvaluation of the single currency) a trend that favours imports from the United States and China rather than from other members of the Union. The Commission's expectations were particularly unrealistic concerning the international role of the European currency. The dollar remains the global currency and despite occasional signs to the contrary, the euro's share in international foreign exchange reserves comes nowhere close to suggesting a displacement of the dollar. But as already noted, EMU was, first and foremost, a political move: to make the integration process irreversible, and to enhance Europe's power on the international stage. Also eastern enlargement was supposed to be part of a strategy to 'create a superpower on the European continent that stands equal to the United States'.10 This geopolitical aspect of enlargement has been strongly criticized by Heinrich August Winkler. The distinguished Berlin historian sees the continuous geographical expansion of the EU as an expression of 'European Bonapartism'. ${ }^{11}$ He is particularly critical of the 'fraud' (Lebensluege) of Germany's European policy, which consists in maintaining that there is no contradiction between widening and deepening, in fact that widening will necessarily lead to deepening - an illusory doctrine advanced in 1997

\footnotetext{
${ }^{8}$ Commission of the European Communities 'One Market, One Money' (1990) 44 European Economy.

${ }^{9}$ Cited in H. Zimmermann, 'Ever Challenging The Buck? The Euro and the Question Of Power in International Monetary Governance', in F. Torres, A. Verdun, C. Zilioli and H. Zimmerman (eds) Governing EMU (Florence: European University Institute) 233-247.

${ }^{10}$ Former Commission President Romano Prodi, as quoted by The Economist of 24 April 2003.

${ }^{11}$ The title of his article in the Frankfurter Allgemeine Sonntagszeitung of 17 April 2005.
} 
to justify eastern enlargement. What Europe does not need, writes Winkler, are ahistorical utopias, such as the end of the nation-state, the existence of a European nation, and 'the wish of geostrategists like Joschka Fischer, Volker Ruehe and Guenter Verheugen to push the domain of the EU to the borders of Syria, Iraq and Iran, so that Europe may finally become a world power'.

I mention this aspect of enlargement in order to call attention to an often overlooked analogy between EMU and the steady expansion of the borders of the Union. ${ }^{12}$ In this presentation, however, I am mainly interested in the policy and institutional implications of enlargement, particularly in its implications for the Single Market, see section 4. Remember that new Member States have to accept EMU as part of the acquis communantaire. They must of course satisfy the Maastricht parameters, which however are purely financial and thus are only indirectly linked to the real economy and to general socioeconomic conditions. For example, Latvia, the poorest of the new Member States admitted in 2004, in 2001 had a budget deficit of 1.6 per cent of GDP and a public debt of only 15.9 per cent. In 2006, Bulgaria had a public debt of 32 per cent of GDP and a budget surplus of 2.3 per cent. Thus, like Latvia, it amply satisfied two key parameters for membership in EMU; but its population (of about 8 million) has decreased by more than a million units since 1992, and infant mortality (1.04 per cent) is almost three times the EU-15 average. The possibility of harmonizing national laws and regulations is undermined by a high level of heterogeneity: if countries have significantly different policy preferences, the regulations that maximize social welfare will be different rather than harmonized. This is true even in the case of minimum harmonization - unless the minimum European standard is so low as to be exceeded by all national standards, in which case it is simply irrelevant.

Again, if EU-15 was not an optimal currency area, this is a fortiori true of EU27 , and in such a large and heterogeneous group of countries the probability of asymmetric shocks will increase significantly. This means that some countries may experience a boom and inflationary pressures while at the same time others experience deflationary forces. As a result, the constraints imposed by a one-sizefits-all monetary policy may entail too high costs to make monetary union acceptable in terms of an economic calculus of benefits and costs. Hence, countries that now consider the economic benefits of monetary union greater than the costs may very well think differently in the enlarged Union. In spite of the warnings of distinguished economists and policymakers - who considered EMU a premature, if not an ill-conceived, project - on 1 January 2002 the euro was introduced among enthusiastic predictions of faster economic growth, greater productivity, significant reductions in transaction costs, and price stability. Today it is generally acknowledged that these forecasts, like those made in the early 1990s, were much too optimistic. Even a 'good European' like Mario Monti, for eight years Single Market and then Competition Commissioner in Brussels, in an interview published by the Italian newspaper Sole-24 Ore on 24 November 2005, 
admitted that monetary union has so far failed to produce the positive results that had been expected. The euro, according to Professor Monti - a respected monetary economist - is 'a currency in search of a single European market', which does not yet exist because of the protectionism still practiced by the national governments, and the reluctance of the same governments to undertake the necessary structural reforms. In 1990 the Commission was arguing that the single currency was needed in order to enhance the credibility of the Single Market project; now we are told that it is the euro which needs a Single Market in order to produce all its potential benefits. After eastern enlargement, however, the achievement of a Single European Market looks more problematic than when the project was launched (see section 4).

In sum, monetary union and large-scale enlargement, far from being the crowning achievements of the Monnet method of integration by stealth, seem to interact in ways that make the attainment of their ambitious goals increasingly difficult, and may even compromise the achievements of the past. Rather than 'One Market, One Money' we may have a Union split into two, if not three, camps: the de jure (UK, Denmark) and de facto (Sweden) opt-outs; the present and future members of the euro-zone; and, if experts such as Harvard's Kenneth Rogoff are right, the future drop-outs - countries with a large public debt, like Italy and Portugal, which in the next 5-10 years, may be forced to abandon the common currency. If this split of the Union were permanent, its future implications would be as far-reaching as they are ill-understood (or deliberately ignored) today. What is already fairly obvious is the contradiction between the centralization of monetary policy and the mutation of the fairly homogeneous EU15 into a highly heterogeneous EU-27. This contradiction, in conjunction with farreaching transformations in the European and the world economy, raises the question whether full economic integration, let alone political union, is still a realistic goal.

\section{THE IMPORTANCE OF UNINTENDED CONSEQUENCES}

According to Karl Popper the main task of the theoretical social sciences is to trace the unintended consequences, and more especially the unwanted consequences, which may arise if we do certain things. While conspiracy theorists assert that all events, even those which at first sight do not seem to be intended by anybody, are intended results of the actions of people who are interested in these results, Sir Karl points out that not all consequences of our actions are intended or desired. In fact, the view that it is the task of the social sciences to discover the unintended consequences of human actions brings these sciences very close to the experimental natural sciences: both lead to the formulation of technological rules -

12 Other analogies are discussed in G. Majone, Dilemmas of European Integration: The Ambiguities and Pitfalls of 
constraints - stating what cannot be done. ${ }^{13}$ In the first section of this paper the unanticipated consequences for European integration of the collapse of the Soviet empire were mentioned. In section 2 another unintended consequence, this time of EMU, was also noted: instead of strengthening the Single European Market and making the integration process irreversible, the introduction of the single currency has split the Union into two, in the future possibly three, camps. An even more unintended consequence of EMU may be growing popular dissatisfaction with the suboptimal economic performance of the Union, as explained below.

After the phase of very rapid catch up with the United States in the first postwar decades, convergence in the levels of per capita income stopped at the beginning of the 1980s and has remained unchanged since, at around 70 per cent of US level. While the American economy was generating employment as well as maintaining working hours, Europe's employment performance was weak and working hours fell consistently. What is even more worrisome, the rate of growth of productivity has been declining since the mid-1990s. Annual growth in national output for every hour worked in the EU-15 averaged 1.4 per cent between 1995 and 2005, compared with 2.4 per cent in the US. The fact that this productivity gap has persisted for the entire decade 1995-2005, that is to say, over a full business cycle, suggests that the erosion of European productivity levels is by now a structural problem - according to some experts, the result of insufficient technological innovation, and of labour markets not competitive enough to force companies to drive productivity higher. Thus, far from being able to catch up, and then surpass, the American economy - the goal set by the heads of state or government of the EU at the Lisbon Summit of March 2000 - the Union will find it increasingly difficult to maintain its unsatisfactory performance.

The desire to improve poor European economic performance has driven EU policy over the last thirty years: from the Single Market Programme, which was meant to provide an answer to perceived 'Euro-sclerosis' in the mid-1980s, to EMU in the 1990s, and the 'Lisbon process' at the beginning of this decade. At the summit held in the Portuguese capital in March 2000, the Council of the EU announced two extremely ambitious objectives: by 2010 the EU should become the most competitive, knowledge-based economy in the world; in the same period it should grow at an annual average rate of 3 per cent, so as to create 20 million new jobs. However, the latest Commission data show that far from closing the gap, and then overtaking the US economy, the EU as a whole continues to lag behind in terms of productivity, employment and, in most recent years, also in growth rates. In fact, as a result of the mid-term evaluation, the 2010 target was no longer mentioned in the conclusions of the Spring 2005 European Council meeting. These persistent failures show once more that the policies and institutions of the present EU are no longer able to meet the challenges posed by the contemporary economy -globalization, strong international competition, and the explosive growth of the services sector.

Integration by Stealth (Oxford: Oxford University Press, 2005) 108-111, and in $n 7$ above, chapter 3. 
Coming back to the unanticipated consequences of monetary union, the point I wish to stress is that in pre-EMU days, complaints about the poor economic performance of the EU could be answered by reminding the critics that Community competences did not include macroeconomic policymaking. Even in policy areas of Community competence, it was difficult for ordinary citizens, and sometimes even for the experts, to allocate responsibility for poor outcomes as between 'Brussels' and the national governments. The centralization of monetary policy, and the constraints on the fiscal autonomy of the national governments imposed by the Stability Pact, have changed the situation dramatically. Unlike most policy decisions taken in Brussels, the decisions taken in Frankfurt are widely advertised, and their consequences, whether on home mortgages, on consumer credit, or on the availability of publicly-provided services, have a direct impact on the welfare of all the citizens of the euro area, indeed of the entire EU. For the first time, the practical implications of a European policy are immediately perceived, not just by special interest groups but by the average citizen. Hence, another unintended consequence of EMU is likely to be a stronger popular demand for greater effectiveness of EU policies - not just in the monetary field, but more generally- and for a better accountability framework. By the same token, poor economic performance will pose more of a threat to the credibility and legitimacy of EU institutions. Not by chance, the reasons given by French and Dutch voters for their rejection of the Constitutional Treaty were mostly of a socioeconomic nature: unemployment, a stagnating standard of living, price increases allegedly caused by the introduction of the euro, and fear of immigration from the new Member States. This fear is quite widespread: in a 2006 survey by Eurobarometer on 'The Future of Europe', 63 per cent of respondents in the EU15 (70 per cent in Austria and France) believed that enlargement would create unemployment, up from 43 per cent in 2003.

\section{EASTERN ENLARGEMENT AND THE COMPLETION OF THE SINGLE MARKET}

In addition to the popular fear of immigration from the new Member States, the latest enlargements will have a number of other unwanted consequences. Of these the most important one from the viewpoint of market integration will likely be the much increased heterogeneity in socioeconomic conditions across Member States. The implications of such heterogeneity for market integration are made more serious by recent structural changes in the European economy, in particular the fast growth of the services sector: between 1980 and 2000, the share of services in the EU economy increased by 13 percentage points to 70 per cent. The services sector - which also accounts for more than 50 per cent of employment - provides

${ }^{13}$ K.R. Popper, Conjectures and Refutations (London: Routledge, 1969) 342-343. 
two telling examples of the difficulties currently facing the Single Market project. In November 2005, after two years of studies, discussions, and consultations, the European Commission decided to withdraw its draft directive for the liberalization of port services. Originally acclaimed as the most important liberalization measure in the area of transportation, the directive proposed to eliminate cargo-handling monopolies by allowing shipping companies to use their own staff to unload cargo, to set limits to permissible state aid in this sector, and generally to stimulate competition among the ports of the EU. The directive had been approved by the Council in 2002, but rejected by the European Parliament in 2003. Faced by the opposition of the EP and of the trade unions, the new Barroso Commission progressively softened many of the proposed measures, to the point of making the revised text, in the opinion of many observers, practically useless. Finally, in one of its worst debacles in recent years, the Commission decided to withdraw even the weakened version of the port services directive, implicitly admitting that it considered itself politically too weak to face the combined opposition of the EP and of the port workers, one of Europe's most protected labour forces. However, the heart of the docks directive's problem was not, or not only, political opposition, but the fact that it was too inflexible to be adapted to conditions in different European countries. According to Robert Wright, writing in the Financial Times of 18 January 2006, most of the rules were aimed at the model of port operations in continental Europe, where typically a state-owned port authority owns the quays and underwater areas. Hence, such legislation took little account of the needs of most large British ports, which are privately owned. Analysts familiar with the situation in Britain even doubt that the UK ports market suffers from the market failures which seem to be evident in other countries, such as France.

The variety of port regimes and port services in western Europe, however great, is nothing compared to the variety of conditions prevailing in the enlarged Union in the area of general services. Given the size of the services sector in the modern economy, a common market for goods, which was more or less achieved under the old Single Market Programme, represents only the beginning of market integration. Unfortunately, in a very heterogeneous Union the integration of the services sector looks quite problematic. 'Is Europe still capable of moving forward?' asked the editorial of the French newspaper Le Monde of 16 February 2006. The topic was the draft proposal of the general services directive then being considered by the European Parliament. The editorialist of the left-liberal newspaper posed very clearly the dilemma facing the EU today. On the one hand, the integration of the market for services, now still largely regulated at the national level, is simply indispensable: with agriculture and industry no longer able to create new jobs, only the services sector could significantly contribute to a reduction of the high level of unemployment in the euro zone. On the other hand, in a socially and economically highly differentiated Union, this integration poses serious social problems, especially with respect to wages. The original draft directive had been worked out in 2004 by Commissioner Frits Bolkestein, responsible for the Internal 
Market in the Prodi Commission. The idea was to circumvent the well-nigh insuperable obstacle represented by the harmonization of a bewildering variety of national regulations, by applying the country-of-origin principle, which would have guaranteed that, with the exception of environmental and safety standards, companies could apply their domestic labour law when providing services abroad. It will be recalled that the Single Market Programme strategy for services was based precisely on the country-of-origin principle. This principle - which had already been introduced in the 1980s in the areas of banking and financial services, as a direct application of mutual recognition - was seen as the only viable alternative to the centralized harmonization of national laws and regulations. Thus, the original Bolkestein directive was in line, not only with the liberalizing, procompetition philosophy of the treaties, but also with the mutual-recognition doctrine of the European Court of Justice, as stated in the Cassis de Dijon judgment and further extended by the Commission to the free movement of people and services. In spite of this impeccable pedigree, the draft of the general services directive immediately sparked widespread concerns among West European trade unions about lower wages, 'social dumping', and an influx of workers from the new Member States of eastern Europe - the same concerns which played a significant role in the rejection of the Constitutional Treaty by the French and Dutch voters in 2005. Faced by intense political opposition, the Commission prepared a softer version of the directive, seeking to address many of the concerns expressed by the European Parliament. A compromise between the two major political groupings, the European Peoples Party and the European Socialist Party, made it possible for the EP to accept the revised version, from which, however, the country-of-origin principle, and with it the whole philosophy of mutual recognition, had disappeared. At the same time, the watered-down version triggered a backlash from East European countries - which as low-cost countries stand to benefit most from price competition among services providers - and also raised fears that the text approved by the EP, with its many exceptions and derogations, could pave the way for future court challenges. It remains to be seen whether the Council will succeed in reinstating the country-of-origin principle; what seems certain is that there will be no integrated services market in the EU for quite some time, if ever.

The fate of the port services and general services directives, combined with the resurgence of protectionism and economic nationalism - or 'economic patriotism', as French Prime Minister de Villepin prefers to call the attempt to create 'national champions' and to insulate them from competition - shows that the goal of economic, let alone political, integration, can no longer be taken for granted. It seems likely that the original draft of the services directive, including the country-of-origin principle, would have been approved in the old EU-15, where wages and social entitlements do not differ significantly. It will be recalled that the idea of mutual recognition rests on the empirical assumption that 'the objectives of national legislation... are more often than not identical'. Only if this assumption is factually correct does it follow that 'the rules and controls 
developed to achieve those objectives, although they may take different forms, essentially come down to the same thing, and so should normally be accorded recognition in all the Member States'. ${ }^{14}$ In other words, mutual recognition can only work among countries roughly at the same level of socio-economic development. Hence the double hurdle facing European regulators today: ex ante harmonization is technically infeasible because of the variety and complexity of the national regulations of services, while mutual recognition and the country-oforigin approach are politically infeasible in a highly heterogeneous Union. Paradoxically, after the introduction of the common currency and the near doubling of EU membership in the space of a few years, one has to worry about the future of the Single European Market. Many of the same people who oppose the 'neo-liberal' philosophy of the Bolkestein directive also maintain that the EU should be much more than a free trade area: it should have a strong social and political dimension. With the services sector - more than two-thirds of the economy - still largely regulated at the national level, however, it can no longer be excluded that the enlarged EU may regress, if not to the stage of a free trade area, then to that of a customs union, with some elements of a common market for goods.

\section{THE LIMITS OF EUROPEANIZATION AND EURO-CENTRICITY}

One of the themes suggested by the organizers of these lectures is how institutional trajectories took off in ways that were not anticipated when the Single European Market project was launched, and the challenges and dilemmas posed by this. I presented my views on these matters in the preceding sections, where I tried to show how large-scale projects meant to widen and deepen European integration, in fact produced consequences challenging the entire process. The organizers also mentioned the issue of 'Europeanization,' and how it has reshaped market institutions and practices. In the present section I intend to discuss some unintended consequences of Europeanization and of euro-centricity. In recent years the phenomenon of Europeanization has attracted a considerable amount of academic attention, probably out of proportion to its real significance. In fact, the evidence suggests that the influence of the European level on the policies and institutions of the Member States, never quite as significant as some scholars imagined, is actually decreasing. Former Commission President Romano Prodi believed that only by applying the Community Method to all European policies would it be possible to counteract the growing diversity and fragmentation of the Union. This would imply extending the Commission's control of the policy agenda even to areas, such as Justice and Home Affairs, where the national governments enjoy a comparative advantage in terms of expertise and material resources.

${ }^{14}$ Commission of the European Communities, 'Completing the Internal Market' (1985) COM(85), 310 
During a five-year transitional period, 1999-2004, both the national governments and the Commission were entitled to advance policy proposals in the communitarized parts of JHA. Given the Commission's limited experience in this area, and the political sensitivity of the issues arising in JHA, the decision to allow a competition of policy ideas, from both national and supranational sources, was wise. By the same token it was a mistake to return to the Commission's monopoly of legislative initiative at the expiration of the transition period. Just as the Community lacks the expertise and institutional maturity to exclude the participatory role of national authorities in the harmonization process, so recognizing the participatory role of national governments in the generation of policy ideas, at least in some areas and subject to veto by the European institutions, would be a realistic and fruitful way of reforming the Community Method.

An important reason for the decreasing influence of the European level is precisely the comparative advantage of national policymakers in terms of cognitive and material resources, not only in JHA but more generally. In fields as varied as telecommunications, environmental protection, and consumer protection, some national policies are by now significantly more advanced than the corresponding European policies, which often cannot go beyond least-common-denominator solutions. In addition to greater capacity for institutional and policy innovation, greater resources, and vastly superior implementation capacities, national policymakers have at their disposal policy instruments that are unavailable to European policymakers. For instance, EU environmental policy lacks a key policy instrument like taxation - recall the ill-fated proposal of a European carbon/energy tax.

Again, today many national regulators are at least as competent as their European counterparts. Take the case of competition policy. When the Treaty of Rome was drafted, only Germany had a well-developed competition policy and an effective competition regulator. The other founding members of the EEC had to develop this policy almost from scratch, largely following European competition rules. At present, most Member States have competition authorities with a satisfactory level of technical expertise, and the power to impose significant remedies: the EU no longer sets the pace in this policy area. The Directorate General for Competition is generally considered the most expert among the Commission services, as well as the one with the strongest treaty-based powers. However, serious doubts about its expertise have been raised when the Directorate suffered three consecutive defeats at the Court of First Instance (CFI), in high-profile cases over merger decisions. In the Airtours case of June 2002, the CFI in annulling the Commission's decision 'used language that was severely critical both of the Commission's procedure and of its substantive assessment of the alleged collective dominance situation created by the merger'. ${ }^{15}$ In September 2003 the same court ruled that a heavy fine imposed on a shipping cartel, was

final (Luxembourg: Office for Official Publications of the European Communities) 17. 
illegal. This last decision raised fresh doubts, not only over the expertise, but also over the procedures used by the European competition authorities.

While the influence of the European level is diminishing, the importance of national regulators continues to grow, especially in economic (sectoral) regulation where Member States have always resisted any significant Europeanization. The broad discretion of the national regulators is often the price that has to be paid in order to get the Council's approval of the regulations proposed by the Commission. For instance, the liberalization of the electricity industry became politically feasible only after the possibility of nationally differing regulatory regimes was allowed. The latest Commission's proposal to establish a European energy regulator to police access to the national grids was flatly rejected by the energy ministers of the, then, $25 \mathrm{Member}$ States at a meeting on energy problems held in Brussels in mid-March 2006. On this occasion, the German representative stated quite clearly that no new European agency was needed in order to improve competition: better cooperation among the national regulators would be sufficient. In the field of telecommunications the idea of a European agency was rejected by the national governments and by most industry representatives already several years ago. The present regulatory framework for telecommunications is highly decentralized and relies heavily on the work of committees of national experts, such as the Open Network Provision (ONP) Committee established in 1990. Under the system created by Directives 2002/19-22, the Commission draws up a list of telecommunications markets that are in principle candidates for regulation. Each national regulatory authority considers whether competition is 'effective' in these markets. A market without effective competition is subject to regulation, but it is up to the national authority to decide which type of regulatory regime is to be used. National regulators present the results of their considerations to the Commission and to their peers, together with whatever information is needed to ensure coherence of telecommunications regulation across the EU. The Commission and the other national regulators have been given veto power over certain important decisions of national regulators, such as which markets to regulate. Many questions are still unresolved, however; for instance, whether the Commission's list of markets that are in principle candidates for regulation is binding on the national authorities. The legal uncertainty that prevails until this and other matters are resolved is itself a major obstacle to economic activity, in particular to market entry by new companies. ${ }^{16}$ It is at any rate clear that the role of the European institutions in the field of telecommunications - where the legal basis for regulatory intervention is provided by national law, guided by various European directives, rather than by treaty - is rather weak.

The one significant exception to the absence of economic regulatory bodies at European level is of course competition policy. Contrary to what is sometimes written by political scientists, however, the European competition regulator is not

${ }^{15}$ D.G. Goyder, EC Competition Law (New York: Oxford University Press, 4th ed, 2003) 392.

${ }^{16}$ A. Sapir, P. Aghion, G. Bertola, M. Hellwig, J. Pisani-Ferry, D. Rosati, J. Vinals, and H. Wallace, An Agenda for a Growing Europe (Oxford: Oxford University Press, 2003) 81-82. 
the Commission's Directorate General Competition, but the entire Commission deciding as a collegial body. This means that in some situations, especially in merger cases, European decisions are highly politicized, rather than being based exclusively on competition principles. Proposals to establish an independent European Competition Authority have always been rejected by the Commission and by a majority of Member States. Instead, the new Regulation 2003/1 introduces a significant decentralization and sharing of enforcement power with the national anti-trust authorities. Unable to handle the increasing volume of work, the Commission has agreed to surrender its monopoly over the application of Article 81(3) of the EC Treaty, allowing the Member State authorities to rule on exemptions to the general prohibition of anti-competitive agreements. Under the previous procedure, only the Commission could decide whether such prohibition could be declared inapplicable under Article 81(3), i.e., in case 'the agreement in question contributes to improving the production or distribution of goods or to promote technical or economic progress, while allowing the consumers a fair share of the resulting benefit'. Now that assessment is delegated to national courts and national competition authorities, although the Commission reserves the right to take any given case into its own hand. Concerns have been expressed about the implications of Regulation 2003/1, especially about the consistency of decisions across jurisdictions. Much hope is placed on the network of national competition authorities and the Commission.

Yet another reason for the weakening influence of the European level is, paradoxically, the euro-centricity of many EU regulations - a feature of Community policies that is increasingly resented by national regulators wishing to be independent not only from national governments, but also from 'Brussels'. One could even speak of a more general euro-centric mentality. For instance, to say, as the German chancellor Angela Merkel did at the Brussels summit of 23-24 April 2006, that what are needed today are European, rather than national, champions, is to reveal the limits of euro-centric mentality: in the age of globalization what Europe needs, presumably, are more global, rather than European, champions. The most dangerous consequences, at any rate, are in are in the area of EU policies, where euro-centricity can be shown to be a direct consequence of the Monnet method of integration by stealth. Under this method, European policies are largely epiphenomenal - the by-product of decisions taken to pursue a number of different objectives, in primis the political objective of deeper integration. For example, over its more than 20-year history, the Common Fisheries Policy (CFP) has largely failed in its aim of conserving fishery resources, notwithstanding its seeming institutional advantages over other international fisheries regimes. The problem is that the CFP has been shaped more by concerns about Community powers than about effective conservation measures. According to two analysts 'the underlying principles of the CFP ... have more to do with reinforcing the concept of European unity and co-operation than with effective management of a seriously depleted, highly sensitive and unstable resource. The CFP is a political statement neatly aligned with the Community's general principles, and designed to avoid 
rocking the European boat'. ${ }^{17}$ Also the recent telecommunications directives have been criticized for being insufficiently aware of the global dimensions of the industry, and for representing 'just attempts of the Commission to push Europeanization forward'. 18

A classic example of the limits of euro-centricity is provided by the failure of the European Commission to have the Precautionary Principle (PP) accepted as a 'full fledged and general principle' of international law. ${ }^{19}$ As a matter of fact, the EU's commitment to, and application of, the principle has been repeatedly criticized by the World Trade Organization (WTO), by the United States, and by many other developed and developing countries. What international organizations and third countries fear is that something as poorly defined as the PP may be too easily misused for protectionist purposes. Such fears are fed by episodes like the beef hormones dispute which for years has opposed the EU to some of its major trade partners. In this dispute the Commission found itself in the position vis-à-vis the WTO which various EU Member States have found themselves vis-à-vis the Community, being sanctioned for introducing a public health and consumer protection measure which was not sufficiently supported by scientific evidence. ${ }^{20}$ The WTO's Dispute Resolution Panel decided against the EC; the Appellate Body agreed with the Panel that the EC had failed to base its measure on a risk assessment and decided against the EC essentially for two reasons: because the scientific evidence of harm produced by the Commission was not 'sufficiently specific to the case at hand'; and, second, because 'theoretical uncertainty' arising because 'science can never provide absolute certainty that a given substance will never have adverse health effects' is not the kind of risk to be assessed under Article 5(1) of the WTO Agreement on Sanitary and Phytosanitary Measures. Actually, it is easy to prove that the PP either restates the obvious (for example, when it is interpreted as meaning that incomplete scientific knowledge is not a valid excuse for regulatory inertia), or else it violates the basic logic of decision making under uncertainty. A comparison with the best international practice in risk regulation reveals a number of other shortcomings of the precautionary approach, of which the most serious is probably the absence of a methodology for the rational setting of regulatory priorities. ${ }^{21}$

As these examples demonstrate, the Brussels authorities are prone to forget that regulation is increasingly an international activity, subject to peer review and scholarly criticism, and open to comparisons with the best international practice. They also forget that for many problems the EU is far from being an optimal

\footnotetext{
${ }^{17}$ Cited in D.C. Payne, 'Policy-making in Nested Institutions: Explaining the Conservation Failure of the EU's Common Fisheries Policy' (2000) 38 Journal of Common Market Studies 303, 312.

${ }^{18}$ C. Engel, 'European Telecommunications Law: Unaffected by Globalization?’ (2002) Working Paper, Bonn: Max-Planck Institute 15.

19 Commission of the European Communities, 'Communication from the Commission on the Precautionary Principle' (2000) COM(2000) 1, Brussels.

${ }^{20}$ G. de Búrca, and J. Scott, 'The Impact of the WTO on EU Decision-making' (2000) Harvard Jean Monnet Working Paper 6/2000.

${ }^{21}$ n 12 above, 131-136.
} 
regulatory area, being either too small or too large with respect to the relevant negative externalities. For both reasons, national regulators tend to oppose eurocentricity. They are aware that their reputation depends on finding efficient solutions to concrete problems, rather than in their commitment to political objectives related to European integration. The multiplication of transnational regulatory networks is an indication of this growing opposition. Membership in broader international networks, such as those operating under the auspices of the Organization for Economic Cooperation and Development (OECD), helps national regulators avoid a narrow regional focus which in some cases leads to the international isolation of the EU. A regulatory authority that sees itself as a member of a group of agencies pursuing similar objectives and facing analogous problems, rather than as part of a bureaucracy pursuing a variety of objectives, is more motivated to defend its professional standards and policy commitments against external influences, and to cooperate with the other members of the network. This is because the agency executives have an incentive to maintain their reputation in the eyes of their international colleagues. Unprofessional, selfseeking or politically motivated behaviour would compromise their international reputation and make cooperation more difficult to achieve in the future. Thus, a network facilitates the development of behavioural standards and working practices that create shared expectations and enhance the effectiveness of the social mechanisms of trust and reputation.

This explains why national regulators increasingly organize their transnational (European and extra-European) networks outside the Community framework. An example from the telecommunications sector is the Independent Regulators' Group, which originated from the meetings of presidents of the various national regulatory authorities. According to Eberlein and Grande, this group rejected Commission attempts to incorporate its coordination activities into the Community structure.22 Also the Council of European Energy Regulators, established in 2002, sees itself as an independent coordinating body of national regulatory authorities. Its main function is the dissemination of 'best practice' examples, using for this purpose the European forums for electricity and gas regulation.

\section{A EUROPE OF CLUBS?}

Transnational regulatory networks are one particular instance of the flexible institutional arrangements now emerging, more or less spontaneously, in a number of policy areas. As was emphasized in the preceding pages, growing heterogeneity in the Member States' socioeconomic and geopolitical conditions, and hence in policy preferences, makes it impossible to enact rules that are both uniform and

${ }^{22}$ B. Eberlein, and E. Grande, 'Beyond delegation: transnational regulatory regimes and the EU regulatory state' (2005) 12 Journal of European Public Policy 89. 
efficient. Efficiency (in the Pareto sense) is always relative to some specific set of actors whose preferences are being taken into account. In the EU case, where preferences vary widely among countries and regions, uniform rules must be inefficient, i.e., reduce aggregate welfare. It follows that future constitutional reforms ought to favour all types of welfare-enhancing voluntary associations, whether or not they are 'aimed at furthering the objectives of the Union, and at protecting and serving its interests' - the euro-centric condition imposed by the treaties on enhanced cooperation, the state-centric equivalent of which any liberal would reject at the national level. Aggregate welfare ought not to be sacrificed to the dogma of straight-line evolution (orthogenesis) of the Union.

Already in the early 1990s, it will be recalled, the perceived loss of overall coherence of the system, and the likely effect on the acquis communautaire of the many opt-outs and derogations contained in the Maastricht Treaty, attracted much critical comment. The loss of coherence was said to be fatal by those who, like Professor Curtin, believed that the commitment to 'ever closer union among the peoples of Europe' implies that integration should only be one way. With the benefit of hindsight, it is easy to see that the various forms of differentiation or flexibility which appeared in the Treaty were indications of an emergent strategy for achieving progress in politically sensitive areas, even at the price of a certain fragmentation of the system (see section 1). The aim of greater flexibility was given official recognition by the Amsterdam and Nice Treaties. The Treaty of Amsterdam provided, for the first time, the possibility of closer cooperation among subsets of Member States - but always within the same institutional framework, and subject to a number of strict conditions. The Treaty of Nice explicitly extended the possibility of enhanced cooperation to the second pillar (Common Foreign and Security Policy), but military and defence matters were excluded, because of deep disagreements concerning the independence of Europe's military capabilities with respect to NATO, with Germany and France favouring an independent European military capability, which the UK opposed.

Since Amsterdam, the tendency had been to make the use of enhanced cooperation easier, and the draft Constitutional Treaty was meant to reinforce this tendency. Thus, according to Article I-43, one third (rather than a majority) of the Member States would be sufficient to establish enhanced cooperation, as long as authorization was granted by the Council. The members of the European Convention hoped that by encouraging the Member States to work within, or as closely as possible to, the framework of the Union when cooperating among themselves, it would be possible to regulate diversity in a principled way - in the sense that any uses of the relevant provisions must adhere to the objectives of the Union. However, critics of a more flexible approach to integration, in the Commission and in some of the national capitals, insist that far from furthering the objectives of the Union, voluntary associations among some members would in fact undermine its constitutional foundations. It is true that the possibility of enhanced cooperation has never been used so far, but this is presumably due to the strict conditions imposed by the Amsterdam and Nice Treaties. If these 
conditions are relaxed at the same time that national preferences become more varied, then the temptation to form smaller, more homogeneous groupings may become irresistible.

While these critics fear the consequences of any departure from the dogma of straight-line development, the economic theory of clubs views the multiplication of voluntary associations in a complex society as a positive, welfare-enhancing development. ${ }^{23} \mathrm{~A}$ few key definitions and concepts will suffice to present the key ideas of the theory. Pure public goods, such as national defence or environmental quality, are characterized by two key properties: first, it does not cost anything for an additional individual to enjoy the benefits of the public goods, once they are produced (joint supply property); and, second, it is difficult or impossible to exclude individuals from the enjoyment of such goods (non-excludability). A 'club good is a public good from whose benefits particular individuals may be excluded only the joint supply property holds. An association established to provide excludable public goods is a club. Two elements determine the optimal size of a club. One is the cost of producing the club good - in a large club this cost is shared over more members. The second element is the cost to each club member of a good which does not meet precisely his or her individual needs or preferences. The latter cost is likely to increase with the size of the club. Hence the optimal size is determined by the point at which the marginal benefit from the addition of one new member, i.e. the reduction in the per capita cost of producing the good, equals the marginal cost caused by a mismatch between the characteristics of the good and the preferences of the individual club members. If the preferences and the technologies for the provision of club goods are such that the number of clubs that can be formed in a society of given size is large, then an efficient allocation of such excludable public goods through the voluntary association of individuals into clubs is possible. With many alternative clubs available each individual can guarantee herself a satisfactory balance of benefits and costs, since any attempt to discriminate against her will induce her exit into a competing club - or the creation of a new one. The important question is: what happens as the size (or complexity) of the society increases, perhaps as the result of the integration of previously separate polities? It can been shown that under plausible hypotheses the number of clubs tends to increase as well, since the greater diversity of needs and preferences makes it efficient to produce a broader range of club goods.

Think now of a society composed not of individuals, but of independent states. Associations of independent states (alliances, leagues, confederations) are typically voluntary, and their members are exclusively entitled to enjoy certain benefits produced by the association, so that the economic theory of clubs is applicable also to this context. In fact, since excludability is more easily implemented in such a context, many goods which are purely public at the national level become club goods at the international level. The club goods in 
question could be collective security, policy coordination, common technical standards, or tax harmonization. In these and many other cases, countries which are not willing to share the costs are usually excluded from the benefits of interstate cooperation. Now, as an association of states expands, becoming more diverse in its preferences, the cost of uniformity in the provision of such goods can increase dramatically. Hence the theory predicts an increase in the number of voluntary associations, corresponding to the increased demand of club goods more precisely tailored to the different requirements of various subsets of states.

It will be noted that the model sketched here is inspired by a liberal philosophy quite different from the unidirectional thinking of enhanced cooperation. It is no longer a question of subsets of states working closely together to further the objectives of the Union and protect its interests. Rather, the prime reason for forming such voluntary associations is to produce public goods more closely tailored to the needs of the club members than would be possible under uniform Union rules. Again, the aim is to maximize the welfare of the members of each association, not to impose a devotion to the integrationist cause worthy of Hegel's political philosophy. A Europe of clubs would also differ from the proposals advanced by some political leaders in the aftermath of the French and Dutch rejection of the draft Constitutional Treaty. For example, the French foreign minister Douste-Blazy in an article published in Le Monde of 23 September 2005 argued that the rélance of European integration could only take place outside the framework of the present treaties, starting with the group of countries willing to move forward. No member of the Union would be excluded a priori from the avant-garde, but the criteria of admission to this club of 'good Europeans' should be very selective. According to the head of the French diplomacy, his model of a 'small house within the large house' would go beyond the kind of enhanced cooperation envisaged by the treaties. It would include foreign policy, security, and research, as well as fiscal, budgetary, and monetary policy. Douste-Blazy stressed the fact that his model differs from 'variable geometry' in that all inhabitants of the 'small house' would take part in all the common policies of the Union, so that the unitary approach would be, to this extent, preserved. Nothing is said about the large house: whether it needs remodelling, and if so how that should be done.

Also the Belgian prime minister Guy Verhofstadt in his Manifesto for the United States of Europe (as reported by the Frankfurter Allgemeine Zeitung of 20 January 2006) spoke of an avant-garde or 'hard core', initially formed by the countries of the euro area, which should push ahead in the direction of ever closer, social as well as economic, union. Verhofstadt acknowledges that after the recent enlargements the $\mathrm{EU}$ is no longer a homogeneous group, hence the members which are unwilling or unable to join the hard-core group should be grouped in a loose 'Organization of European States'. Somewhat similar ideas had been presented by the former German foreign minister, Joschka Fischer, in a conference held at Berlin's

${ }^{23}$ J.M. Buchanan, 'An Economic Theory of Clubs' (1965) 32 Economica 1; D.C. Mueller, Public Choice II 
Humboldt University on 22 May 2000, which at the time stimulated a far-ranging debate. He was among the first political leaders to resurrect the idea, already advanced after the first enlargements of the Community, that the member states wishing to deepen their political integration should sign a new treaty - the kernel of a federal constitution - in the hope that these pioneers could eventually become a magnet capable of attracting the majority, if not the totality, of the other members of the Union.

These and similar neo-federalist proposals still assume that, if it is not to dissolve in chaos, the process of European integration must necessarily follow a single trajectory. The laggards must eventually join the avant-garde - or drop out. The approach suggested by the economic theory of clubs does not distinguish between pioneers and laggards, since there is no unique ranking of national preferences. Rather, the problem is to find efficient institutional arrangements under some basic rules and policies freely accepted by everybody - tailored to the specific needs and preferences of various sets of countries, or of regions within countries. In practical terms, overall coherence could be ensured by having in each club a Union representative, acting as a coordinator and facilitator - a role similar to that of the federal representative in the American 'regional compacts' (see below). It should be pointed out that the logic of this approach would entail the re-nationalization of European policies when significant heterogeneity in preferences raises serious questions about current arrangements. The main example is of course the Common Agricultural Policy, since the move to income support in lieu of price support, combined with increased diversity as a consequence of enlargement, weakens the rationale for retaining EU competence in agriculture. ${ }^{24}$

As noted above, the EU has already started to experiment, more or less intentionally, with forms of flexibility that are closer to the approach suggested here than to enhanced cooperation as defined by the treaties. Thus, as a unanticipated consequence of EMU, the euro area turned out to be, in some respects, a 'club' within the EU-15. However, the fact that membership is not voluntary for new Member States, but rather part of the acquis, shows how deeply rooted is the idea that integration can only be one way. The influence of this idea can be detected in a number of other policy fields. For instance, the existence of transboundary externalities is often cited as a justification for EU-wide harmonization. In particular, the Commission has argued that where there is potential for transboundary pollution there is often justification for the EU to act, but this is far from being obvious. For most environmental problems the EU is not an optimal regulatory area, being either too large or too small. In a number of cases - the Mediterranean, the Baltic Sea, or the Rhine, for example - the scope of the problem is regional rather than EU-wide, and is best tackled through regional arrangements tailored to the scope of the relevant environmental externality. Selfregulatory organizations encompassing only some states ('regional compacts', such

(New York: Cambridge University Press, 1989). 
as the Delaware River Basin Commission or the Appalachian Regional Commission) have been used in the United States since the 1960s, and in some cases even earlier. As already mentioned, the central government is represented by a federal coordinator who, in many cases, is appointed jointly by the US President and by the governors of the states making up the particular interstate compact. ${ }^{25}$ More recently, organizations including some US states and Canadian provinces have been created in order to control pollution in the Great Lakes region. By pooling their financial, technical, and administrative resources, such consortia are in a better position to deal effectively with their regulatory problems than either by each jurisdiction acting alone or by relying exclusively on centralized regulation which could not be closely tailored to their specific needs.

Again, most people agree that a EU able to speak with one voice could play an important role in international affairs. Official rhetoric goes as far as claiming that the Union has already achieved results in this direction which would not have been possible for individual Member States acting on their own. ${ }^{26}$ Reality is, unfortunately, less rosy. Even when the Member States do not disagree radically, as in 2003 on the war in Iraq, they typically have different priorities in foreign policy. Indeed, the basic flaw in the design of a 'common' foreign and security policy is that the EU pretends to be one of the players at the table of world politics without having first reached a shared understanding on what ought to be treated as a vital European interest. This lack of common understanding is unfortunate, but understandable. According to customary usage, those of our interests are 'vital' that we are ready to fight to preserve. In other words, 'the importance of vital interests comes not necessarily from some intrinsic quality, but rather from what we are ready to do about some infringement of them, real or imagined'. ${ }^{27}$ However, most Member States are extremely reluctant to fight for any reason, preferring to project the model of the EU as soft power - remember the debacles of Bosnia and Kosovo, or the saga of the Rapid Reaction Force which was supposed to be operational by 2003, but will be ready, maybe, only by 2010 . This being the case, the very notion of a vital interest of the EU is, at present, an oxymoron - a combination of contradictory ideas. ${ }^{28}$ Eastern enlargement has made the search of a common European interest even more elusive. Those new Members States which feel threatened by a resurgent Russia look to the United States, not to the EU, for protection. The importance of the American protection becomes clear when one notes, for example, that in some regions of the Baltic republics half of the local population is composed of ethnic Russians, who complain of discrimination. At a minimum, it is to be expected that relations between the EU and Russia will be more difficult than necessary because of the hostility of the new members.

${ }^{24} \mathrm{n} 16$ above, 111

${ }^{25}$ M. Derthick, Between State and Nation (Washington D.C.: The Brookings Institution, 1974).

${ }^{26}$ Commission of the European Communities, 'European Governance' (Luxembourg: Office for Official Publications of the European Communities, 2001) 9.

${ }^{27}$ B. Brodie, Wars \& Politics (New York: MacMillan Publishing Co., 1973) 342. 
A foretaste of future problems was provided by the failure of the EU-Russia summit held in Helsinki on 24 November 2006. At this summit, Poland refused to approve a mandate to the European Commission to negotiate a new cooperation and partnership agreement between the EU and Moscow - an agreement which the older members of the Union strongly supported. Shrewd observers noticed President Putin's relaxed, even amused, reaction to the Polish veto. Apparently the Russian leader realizes that the recent enlargements have significantly weakened the EU's international status, compounding the difficulty of the Union speaking with one voice. Russia's new assertiveness was also demonstrated by Putin's rejection of any suggestion that the Russian energy market should be liberalized along the lines of EU competition rules. The Russian President knows that nowadays energy questions are not dealt with between Russia and the EU, but bilaterally with individual Member States. In such a situation, to insist that the EU should 'speak with one voice' amounts to condemning the Union to remain silent on most important geopolitical issues. The only way to avoid this impasse seems to be, first, to accept that national preferences and priorities in foreign policy will continue to vary widely; and, second, to let subsets of Member States form their own voluntary groupings, subject to the conditions indicated above, namely in the framework of some basic common rules and policies, and with the Union acting primarily as coordinator and facilitator. With good eyesight one can see the emergence of such flexible arrangements in the area of foreign policy. I am thinking, for instance, of what Stephan Keukeleire calls 'EU core groups', ${ }^{29}$ operating within larger contact groups - the latter being set up to coordinate the activities of the international community in a particular area. For example, the contact group recently organized to provide humanitarian and development aid to Somalia includes the UN, the African Union, the Arab League, the EU (represented by the foreign minister of the country holding the presidency of the Union, and by the Commissioner responsible for development and humanitarian aid), the United States, Tanzania, Norway, and a EU core group formed by Italy and the UK, as former colonial powers, and Sweden, as important provider of humanitarian aid. Typically, the members of a EU core group are countries which for historical, geographical, or economic reasons have a particular interest in a given region, and/or are prepared to contribute significant resources to help solve the region's problems. Subsets of Member States operating in Sudan, Lebanon, and Kosovo are other examples of Keukeleire's core groups. While these are at present ad hoc arrangements, there is no reason why they could not develop into more permanent, club-like associations in the future. Such a development would confirm the guess formulated in section 1, that the EU is more likely to undergo a kind of evolution with many side branches rather than orthogenesis, or straightline evolution.

\footnotetext{
${ }^{28} \mathrm{n} 7$ above, ch 3 .

${ }^{29}$ S. Keukeleire, 'EU Core Groups: Specialization and Division of Labour in EU Foreign Policy' (2006) Brussels: CEPS Working Documents.
} 


\section{CAUGHT UNAWARES}

The thrust of my argument has been that the traditional integration methods are no longer adequate to deal with the mutation pressures - economic, social, and geopolitical - confronting the EU today. Some of these pressures are the more or less unintended consequences of long-term processes (such as the tension between globalization and euro-centricity), while other are the unwanted consequences of ambitious projects, such as EMU and eastern enlargement, whose risks were never properly assessed. Instead of the 'One Market, One Money' announced by the European Commission in 1990, we have now a Union split into two, and in the future possibly three, camps; a Single Market the completion of which recedes into the distant future; and growing public awareness that the integration process is not delivering the promised benefits, either in economic or in political terms. Largescale enlargement has not enhanced, but actually weakened, the EU's international status, and raised geopolitical issues that exceed its political and diplomatic capacities; while an unprecedented level of social and economic heterogeneity has greatly increased the welfare costs of harmonization. Not least, by raising the spectre of uncontrolled migrations, enlargement has reinforced the popular view of the Union as contributing to, rather than helping to solve, the problems Europeans are facing today. Of course, any major policy decision is bound to produce, together with the expected benefits, a number of unintended results, some of which could have most serious systemic consequences. This is why crisis management has become a key function in all modern organizations, both private and public.

In contrast, the absence of contingency plans is a peculiar, though seldom discussed, feature of EU decision-making. This absence appears particularly surprising when one thinks of the many endogenous and exogenous shocks to which the Union is exposed today. Hence, it may be useful to conclude this essay by trying to explain why European leaders so often give the impression of been caught unawares by events. The inability to provide a timely and adequate response to the constitutional debacle in 2005 has shown in the clearest possible way that the Union has no machinery for crisis management. The rejection of the draft Constitution did not come as a surprise - either in France and the Netherlands, or in Brussels and in the other national capitals - having been predicted by virtually all opinion polls. What was surprising in both cases were the high voter participation (compared to all previous European elections) and the size of the negative vote: almost 55 per cent against ratification and 45 per cent in favour in France; 61.5 and 38.1 per cent, respectively, in the Netherlands. In an extraordinary meeting in Brussels in early June 2005, the Presidents of the Commission, of the European Parliament, and of the EU Council at first tried to minimize what had happened. They insisted that the ratification process must continue so that at the end of 2006, when the process was supposed to be 
completed, a general reassessment of the situation could be made. Their hopes were dashed by the British decision to postpone indefinitely the referendum originally scheduled for the first half of 2006. Denmark, the Czech Republic, and Poland soon followed the British example, reinforcing the impression of many commentators that the draft Constitutional Treaty was effectively dead. The response of the EU leaders to this second shock was not some concrete decision, no suggestion of a possible exit strategy; only the resigned admission that nothing could be done before the French elections of 2007. As we now know, even this assessment was too optimistic. At the time of this writing (February 2007), EU leaders are still engaged in desultory discussions on what to do about the draft Constitution - with the European elections of 2009 as the new deadline! Compare this behaviour with that prescribed by one of the key principles of crisis management, according to which speed is of the essence, and the first few days' reaction, vital.

Another basic principle of crisis management instructs executives to be on the look out for signs that may foretell a crisis. In early June 2005, an opinion poll published by the popular German magazine Stern indicated that 56 per cent of the Germans would have liked to return to the D-Mark, 48 per cent thought that the problems of the economy were also due to the euro, and 90 per cent made the common currency responsible for the price increases of recent years. According to the same magazine, the German Minister of Finance, the President of the Bundesbank, and a select group of economists had met secretly to discuss the possibility and consequences of a collapse of monetary union. In August of the same year the London Times discussed the hypothesis that Italy might leave the euro zone if the ECB did not loosen its restrictive monetary policy. After the Italian elections of April 2006, Wolfgang Munchau of the Financial Times again conjectured that Italy could decide to return to the lira in order to recover the competitiveness of the national economy - a competitiveness seriously compromised by the appreciation of the euro not balanced, as in Germany, by a moderate growth of labour cost. Some months later, also Kenneth Rogoff - the well-known Harvard monetary economist and former chief economist of the International Monetary Fund - predicted that some countries with a large public debt may be forced to give up the euro in the next five to ten years (see section 2). The reaction of the European Commission to such dire predictions was always the same: 'it is impossible to divorce from the euro', 'there is no possibility of leaving the monetary union', and similar statements meant to stress the irreversible nature of EMU, but in fact masking the lack of contingency plans in case monetary union were to fail, in whole or in part. Even the ECB dismisses doubts about the sustainability of monetary union simply by repeating that the euro - like a De Beers diamond - 'is forever'.

The unwillingness of the European leaders to envisage the possibility of failure - much less to discuss this possibility in public, in spite of all the promises of more democracy and greater transparency - explains why EU leaders are so often caught unawares. But how can we explain this unwillingness, and hence the 
lack of contingency plans? The answer seems to be twofold. ${ }^{30}$ First, the EU's political culture seems to demand total optimism concerning not only the finality of the integration process, but also the uniqueness of its trajectory. Thus, neither the Treaty of Rome nor its subsequent amendments provide clear procedures to be followed should a Member State wish to leave an increasingly diverse Union - a possibility belatedly acknowledged by Article I-59 on 'Voluntary withdrawal from the Union' of the now defunct draft Constitutional Treaty. According to most legal commentators, the silence of the treaties concerning the possibility of leaving the Union implies that secession is illegal under European law. Now, the refusal to admit the possibility of secession seems to be a legacy of the federalist illusions of the early post-war period. In fact, the possibility of secession is a crucial element distinguishing the confederate from the federal model. The nature of the confederate pact as a formal contract among sovereign states implies the right of every member to withdraw when it feels that the contract no longer meets its needs. A federal constitution, on the other hand, is not a contract or a treaty among sovereign states, but an expression of popular sovereignty. Hence the reference to an 'American People', distinct from and superior to, the peoples of the thirteen former colonies in the Preamble to the US Federal Constitution of 1787. The refusal of the federal government to accept secession as a solution to the problems dividing the North and the South was of course the immediate cause of the American Civil War. Thus it is unsurprising that those framers of the Rome Treaty who still considered the United States of Europe a concrete possibility, would not admit that a Member State could voluntarily withdraw.

The thesis that the political culture of the Union demands total optimism is supported by another peculiarity to which I have called attention in a previous publication: the willingness to actually increase the risk of failure - often for political reasons that are never made explicit, in fact are often denied. ${ }^{31}$ The original plans for monetary union envisaged no more than a handful of countries (essentially, the Deutsche-mark bloc, plus France) the structural similarities of whose economies seemed to approach the conditions for an optimal currency area. The final decision to start EMU with eleven, soon to become twelve and now thirteen, countries - a decision made possible by a flexible interpretation of the Maastricht parameters - was dictated by political considerations, such as the hope to make the common currency 'the foundation for Europe's increased power in the world', see section 2. Similarly, the original plans of opening accession negotiations with no more than five countries from Central and Eastern Europe five being the number favoured by the Commission, while the government of Chancellor Kohl would have preferred to start with only Poland, the Czech Republic, and Hungary - were soon superseded by the decision, taken at the Luxembourg European Council in December 1997, to open formal accession negotiations with all ten Central and East European candidates, plus Malta and

${ }^{30} \mathrm{n} 7$ above, ch. 3 .

${ }^{31} \mathrm{n} 12$ above, 110. 
Cyprus. The reason was again political, with each incumbent member state pushing for its own favoured candidate; some leaders hoping that through largescale enlargement 'Europe may finally become a world power' (see again section 2 ); and the Commission attempting to present enlargement as feasible without an increase in the budget, and without demanding too many sacrifices from the incumbent member states.

So much for total, if heedless, optimism. I consider now the second reason for the absence of contingency plans, which has to do with the Monnet method of integration by stealth. 'Monnetism' may be considered a kind of federalist revisionism and there are, in fact, some interesting analogies between the federalist revisionism of the 1950s and the Marxist revisionism of the 1890s. A crucial causal factor in the former case was the realization that the nation state was not going to wither away; in the latter, the realization that Marx's predictions of the impending collapse of capitalism and the inevitability of the socialist revolution were based not on fact, but on wishful thinking. Marxist revisionists 'were not people who abandoned Marxism completely... but those who sought to modify the traditional doctrine...or who held that some of its essential features were no longer applicable in the present state of society'. ${ }^{32}$ Similarly, federalist revisionists ${ }^{33}$ did not abandon orthodox federalism completely; on the contrary, they could legitimately claim that they were keeping alive its legacy and at least some of its intermediate aims in an unfavourable political environment. In both cases, however, the abandonment of the original vision had as a practical consequence a loss of interest in 'ultimate goals' and a concentration on means. Eduard Bernstein, the German founder of Marxist revisionism, summed up its attitude in a formula which became famous as the target of orthodox attack: What is generally called the ultimate goal of socialism is nothing to me; the movement is everything' ${ }^{34}$

Also for revisionists like Paul-Henry Spaak and Jean Monnet, the finality of European integration became increasingly irrelevant; what counted was the movement, the process - especially the creation of European institutions. Lack of interest in the finality of European integration and fascination with the process of institution building were particularly pronounced in the case of Spaak. According to the Belgian statesman, 'everything which tends toward European organizations' was good. Indeed, in 1949 he commended a proposal for common European postage stamps as having equal value with any other proposal. In the words of Alan Milward: 'Any form of integration, any form of common authority in Western Europe, had become the indispensable guarantee for post-war security, and he became increasingly indifferent to what that authority might be or do'. ${ }^{35}$ If one adopts Spaak's criterion that 'everything which tends toward European organizations' is good, regardless of what these organizations might do, then it is

\footnotetext{
${ }^{32}$ L. Kolakowski, Main Currents of Marxism - The Golden Age (Oxford: Oxford University Press, 1978) 98.

${ }^{33}$ Or 'cryptofederalists', see $n 7$ above, ch. 3.

34 Cited in $n 32$ above, 108.

35 A.S. Milward, The European Rescue of the Nation State (London: Routledge, 1992) 324.
} 
easy to be a total optimist, and convince oneself that success is more or less ensured There is, however, one serious problem with this philosophy: one who adheres to it is tempted to overreach oneself, and overreaching brings nemesis upon the overly ambitious. In the cases discussed in this paper, the punishment consists in using the two most important projects of the 1990s to demonstrate the limits of the Monnet method. Even if the predictions of the more pessimistic experts do not materialize, the available evidence is sufficient to conclude that the method of integration by stealth has outlived its usefulness. 